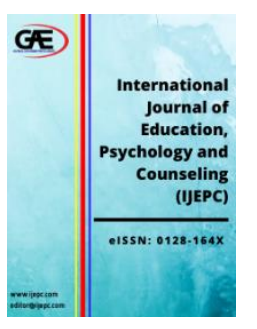

\author{
INTERNATIONAL JOURNAL OF \\ EDUCATION, PSYCHOLOGY \\ AND COUNSELLING \\ (IJEPC) \\ www.ijepc.com
}

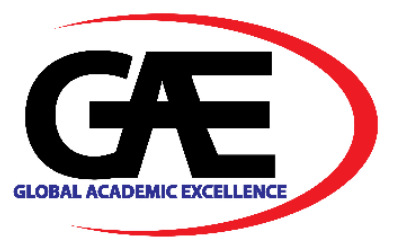

\title{
THE NEED FOR ENTREPRENEURSHIP AWARENESS TO BECOME AN ENTREPRENEUR! A CASE STUDY ON EMPOWERMENT OF ENTREPRENEURIAL ATTRIBUTES OF STUDENTS FROM A PRIVATE INSTITUTION OF HIGHER LEARNING
}

\author{
Bibi Noraini Mohd Yusuf*1, Noorkartina Mohamad², Farah Mastura Noor Azman ${ }^{3}$ \\ $1 \quad$ Faculty of Applied and Human Sciences, Universiti Malaysia Perlis \\ Email: bibinoraini@unimap.edu.my \\ 2 Faculty of Business and Management Sciences, Kolej Universiti Islam Perlis \\ Email: kartina@kuips.edu.my \\ 3 Faculty of Business and Management Sciences, Kolej Universiti Islam Perlis \\ Email: farah@kuips.edu.my \\ Corresponding Author
}

Article Info:

Article history:

Received date: 15.09 .2021

Revised date: 15.10 .2021

Accepted date: 18.11 .2021

Published date: 01.12.2021

\section{To cite this document:}

Yusuf, B. N. M., Mohamad, N., \& Azman, F. M. N. (2021). The Need For Entrepreneurship Awareness To Become An Entrepreneur! A Case Study On Empowerment Of Entrepreneurial Attributes of Students From A Private Institution Of Higher Learning. International Journal of Education, Psychology and Counseling, 6 (44), 13-29.

DOI: $10.35631 /$ IJEPC.644002

\begin{abstract}
:
The entrepreneurial element has now emerged as one of the important pillars in designing appropriate attributes and structures of the academic curriculum covering varied disciplines in all fields of studies in Malaysia's higher education institutions. This study was conducted in Perlis's Islamic University College (KUIPs) campus aimed at understanding these attributes and the entrepreneurship cultural awareness of students' in initiating and identifying appropriate entrepreneurial activities before completing their studies. The study was qualitative in nature involving a group of 20 students randomly chosen from four (4) faculties in KUIPs. Students were interviewed using instant message routes because of the restrictions imposed by authorities in addressing concerns a rising from the COVID 19 pandemic, where face-to-face interviews were disallowed due to health and security factors. The objectives of this study were 1) What are the factors that encourage students to become entrepreneurs on campus? and 2) What are the constraints facing students in becoming entrepreneurs on campus? The results of the study found that there were 3 main factors attributing to students' keen interest to venture into entrepreneurial activities in KUIPs, namely a) keen interest to initiate own business and aspiring to be an entrepreneur after graduation, b) meeting students' basic needs (social entrepreneurship), and c) able to earn extra income to defray living and study expenses. There were 3 constraints discovered in becoming entrepreneurs, namely a) Capital, b) Suitable Location,
\end{abstract}




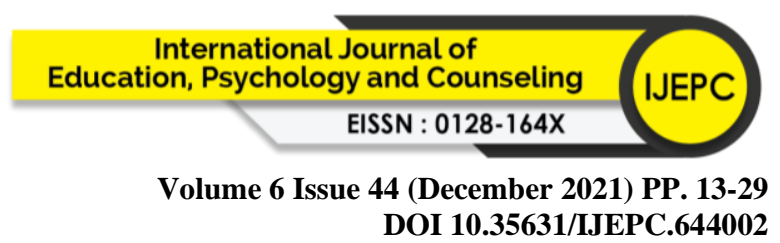

This work is licensed under CC BY 4.0

(ㅇ)(1)

and c) Business Skills to start entrepreneurial activities (entrepreneurial knowledge/skills). The results of this study are most beneficial to those involved in the management of entrepreneurial affairs of students, students themselves, and lastly for the Faculty of Business and Management Sciences in KUIPs (in understanding the current attributes and constraints), there by enabling the faculty to design appropriate entrepreneurship programs and activities in order to nurture and create entrepreneurship cultural awareness for future students.

Keywords:

Social Entrepreneurship, Entrepreneurship Awareness, Entrepreneurial Attributes

\section{Introduction}

Malaysia's higher education sector is currently fast-growing and viable both locally and internationally. The country is increasingly becoming a globally preferred destination for higher education owing to its world-class quality of education coupled with reasonable costs of living. The development of this increasingly competitive sector can be seen with the mushrooming in the number of both public and private higher education institutions (HEI) of learning in the country over the years. The Ministry of Higher Education (MOHE) plays an integral role in creating a higher education ecosystem with having the finest and the best HEIs. These institutions are the main building blocks in the national education ecosystem and training, with a vision to generate first-class graduate thinkers, researchers, scholars, and lastly skilled and semi-skilled workforce in accordance with their respective fields and disciplines. The HEIs are divided into 4 broad categories, namely Private Universities, Private University Colleges, Overseas University Branch Campuses, and College-Level Private Institutions, totaling 436 institutions throughout the country in 2019. This included a total of 10 foreign university branch campuses being opened, which served the dual purpose of turning Malaysia into a reputable regional higher education hub in the future. All these HEIs offer students a wide array and range of skilled and qualified tertiary qualifications.

According to the MOHE, there are presently 20 Public Universities in Malaysia (2021) segregated by 3 broad education disciplines as tabulated in Figure 1 below: - 
Figure 1: 20 Public Universities in Malaysia (2021)

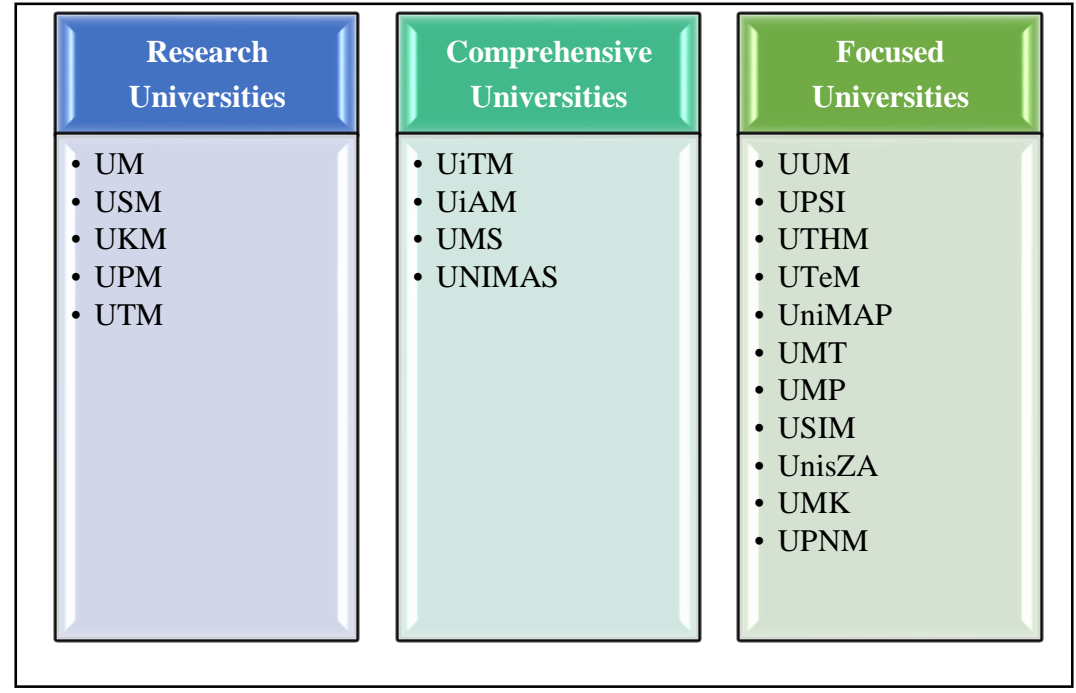

The following Figure 2 depicts the logistics for this category according to the MOHE classifications as of 2019.

Figure 2: Private Universities and Private University Colleges in Malaysia (2019)

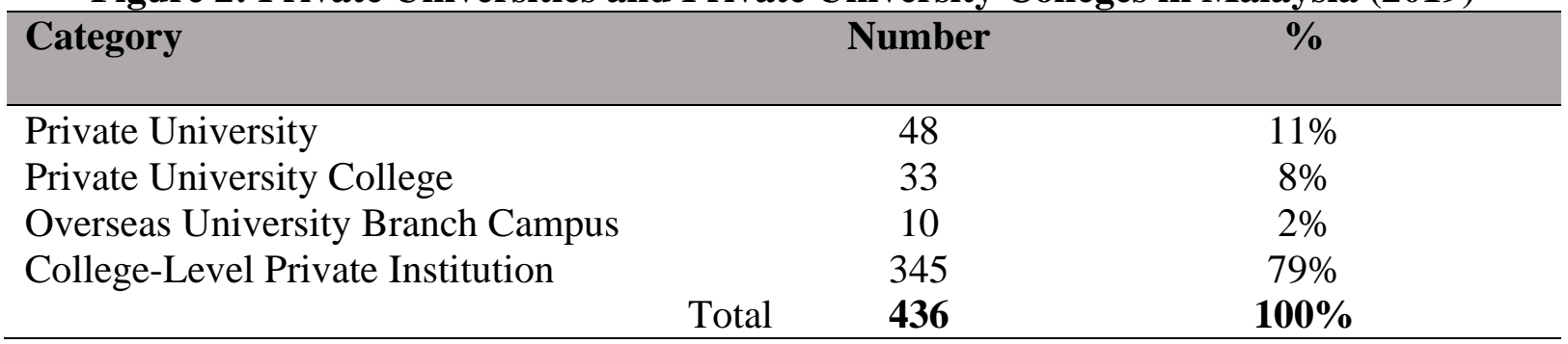

Students graduating nowadays, whether from the public or private HEIs, have the distinct mindset of being job earners, i.e. becoming salary earners, instead of exploring other avenues or opportunities. In fact, in today's fast and changing industry landscape, they should be having the determination and knowledge to become job creators instead. The involvement of college students in entrepreneurship activities is crucial in overcoming the high unemployment rates and in addition, helps to improve and revive the economy [8]. Entrepreneurship activities are the key solution in addressing the unemployment situations that occur in Malaysia today [32][36]. Apart from the unemployment issue, being an entrepreneur can also solve the problems of low-income Malaysians. As much as 6\% of all Malaysians (or 1.9 million population) are earning less than RM1,44.00 per month [26]. Hence, being an entrepreneur is a very good move as it can spin off the economy thereby creating more job opportunities for the local community.

Entrepreneurship itself is both challenging, arduous, demanding, and amazing only to those who can see human needs as initial steps in social development contribution and in starting new ventures. It is related to human behaviors or human actions towards becoming entrepreneurs [5]. The word entrepreneur had its origin from the French word "entreprende" which means "a volunteer who leads a military expedition" [30][19]. However, since the 1940s, the word has been expanded and interpreted to incorporate "the nations of innovations" [30]. 


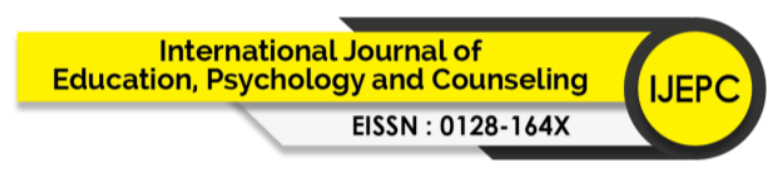

Volume 6 Issue 44 (December 2021) PP. 13-29

DOI 10.35631/IJEPC.644002

Currently, in order to encourage entrepreneurship awareness among students in the universities, in addition to creating programs or activities related to entrepreneurship, there are many other programs at the Diploma, Bachelor's, Master's, and Doctoral levels designed and created so that entrepreneurial knowledge can be cultivated, nurtured and taught to students at the onset. Ministries of Education globally also support this cultivation of entrepreneurship awareness [1]. Vide this study researchers try to understand the factors that motivate students from HEI to become entrepreneurs at the early stages of education and what constraints facing them in achieving their aspirations to become entrepreneurs. It is crucial too for any university management to provide entrepreneurship cultural awareness, entrepreneurship modules, and facilities for appropriate entrepreneurial activities for the empowerment of entrepreneurship attributes among students.

\section{Literature Review}

Students need to be exposed to basic disciplines and knowledge of entrepreneurship, such as introduction to entrepreneurship, finance, digital marketing, business innovation, franchise management, and business plans. Presently, there are basic programs introduced at the university level to cultivate students' interest in becoming entrepreneurs upon graduation, such as having entrepreneurship bazaars and entrepreneurship open days. In 2015, the MOHE has launched an Entrepreneurship Plan (EP) which also embedded the moral and religious attributes in any entrepreneurial activities. According to Zainal Adnan, Mohd Rosdi, Salleh Hudin, and Abd Razak (2019), Pillar 1 in the said EP, titled "Graduate, Entrepreneurial Characteristics and Balanced", these attributes are aimed at injecting moral elements and moral values among students who aspire to become entrepreneurs. Students can actively participate in entrepreneurial activities organised at their respective universities through conferences, workshops, seminars, training, short courses, and entrepreneurship events [33].

\section{Factors Affecting Students Becoming Entrepreneurs}

\section{Interest in Becoming an Entrepreneur}

Entrepreneurs play significant roles in fulfilling social challenges in society. Apart from the initiatives under MHE's EP, which has provided entrepreneurship plans to students, there are also other institutions, companies, and government-linked agencies being contributors and thereby complementing this initiative, by providing arrays of financial assistance, advisory services, and on-site training in Malaysia. Previous research results have stated that the main motivational factors driving entrepreneurship interest are the desire for independence and the need for achievement [43]. The main reason why people became entrepreneurs was motivated by being able to create their own business [38]. The factors that encouraged students to become entrepreneurs included not being salary earners, be self-independent as well as be free to run their own businesses, and lastly, students wanted to start their own business [42].

\section{Meet the Basic Needs of Students in Campus (Social Entrepreneurship)}

Students need to have a clear-cut business plan before becoming entrepreneurs. Besides acquiring basic knowledge of entrepreneurship, students also need to grasp the basic needs and demands for both goods and services of users (fellow students) on the campus. Basic knowledge in business, such as skills, goals, business ideas, business and marketing plans, and a mentor who can guide students in business should be readily available. Students who are able to identify the needs of users, especially the basic needs needed by students on campus, are the ones that can become successful entrepreneurs. One of the important factors for an entrepreneur 


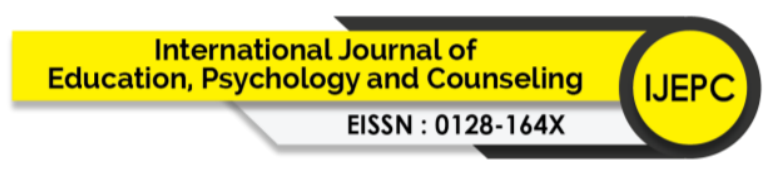

Volume 6 Issue 44 (December 2021) PP. 13-29

DOI 10.35631/IJEPC.644002

to succeed is to be able to identify different business opportunities and growth of the current and existing business environment. Social entrepreneurship can be defined as doing business for a social cause [27]. This concept of (social entrepreneurship or social enterprise) is a powerful new idea, combines real-world solving problems and the role of helping fill the actual human needs [34].

\section{Managing Income and Expenses}

Several past studies have found that one of the factors driving students to become entrepreneurs is to complement family and sponsorship funds to meet monetary obligations on campus such as studies, living, and overheads. There are several factors that encourage students to be entrepreneurs such as being more innovative, becoming role models in the field of entrepreneurship, and be able to achieve personal growth [16]. Entrepreneurship among students is an important building block on campus pushing them to fulfill the basic needs of students. These attributes have created students' intentions to become entrepreneurs. With the availability of numerous business opportunities in the campus environment for certain products or services, then students will begin to be creative and innovative to meet the social development in the university. A conducive environment in society will trigger entrepreneurial intentions to create a new venture [17]. In addition, intentions among students to become entrepreneurs on campus are also driven by several other factors related to income supplement such as wanting to earn more money to meet their own expenses, helping low-income families, and motivations for self-satisfaction and growth [45].

\section{Constraints To Become As An Entrepreneur}

\section{Capital and Financial Resources}

The results of previous studies on the challenges of young entrepreneurs and students who become entrepreneurs have explored these problems from the financial aspect before starting a business. The lack of support from the government in relation to entrepreneurship, chiefly financials, is a major challenge to young entrepreneurs in India [10]. The costs involved in starting a new business are usually related to the cost of asset expenses, operating costs, and the cost of administrative procedures. The problems of capital and financial resources that exist among entrepreneurs who want to start a business are due to several factors, namely lack of personal savings and lack of business start-up skills [44][18]. In addition, the challenge of entrepreneurs in rural areas is a lack of financial resources. It is to be noted too that among the challenges facing entrepreneurs are that young entrepreneurs do not have enough skills and that financial resources are also limited [21]. Hence the government needs to step in to provide such support, such as to inject funds for new business start-ups.

\section{A Place To Carry Out Entrepreneurial Activities}

Inadequate infrastructure for entrepreneurial activities among students is also one of the challenges discovered based on previous studies. A conducive business environment for entrepreneurship activities on campus must have adequate physical facilities to facilitate students to run a business. Facilities such as suitable locations to conduct the business and availability of wet storage spaces are important to create a cultivating entrepreneurial environment to attract their interest in entrepreneurship. In order to cultivate and implement entrepreneurial activities on campus, university management must first provide technical support such as consulting, place of business, financial support, legal counseling, and business plans. Apart from that, university support to encourage students involving entrepreneurship 


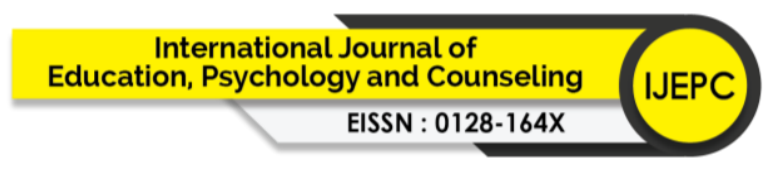

Volume 6 Issue 44 (December 2021) PP. 13-29

DOI 10.35631/IJEPC.644002

activities must include funding, availability of facilities or resources to increase students' exposure to these student-driven businesses [37][24]. It is important to create entrepreneurial attributes and entrepreneurial cultural awareness among students on the campus, especially specifying related guidelines and policies to start a business [3].

\section{Methods of Starting an Entrepreneurship Activity}

Nowadays, entrepreneurship is an important field in society. In overcoming the unemployment issue, graduates tend to venture into the field of entrepreneurship to boost their income either conducting it physically or through an online approach. Nevertheless, entrepreneurship skills among students need to be developed before venturing into unchartered fields. Entrepreneurship skills need to be developed based on education, modules, and entrepreneurship training [25]. University management needs to have cultural awareness in respect of entrepreneurship, availing proper programs and appropriate entrepreneurship modules. In a business, entrepreneurs need entrepreneurship skills such as identifying business opportunities, preparing a business plan, managing operating costs as well as curtailing expenses, and lastly on marketing skills [11]. Apart from that, in order to understand the products and services required by students on campus, market surveys need to be conducted by aspiring student entrepreneurs. This skill is closely related to marketing skills in the entrepreneurship fraternity. There is a lack of skills related to marketing among entrepreneurs causing them not to understand the needs of customers in the market [7]. Skills in marketing such as promotion, advertising, and sales forecast are very important knowledge among students to be successful entrepreneurs [46].

\section{Theory of Planned Behavior}

The Behavior Plan Theory is often used by researchers in studying the relationship between student's intentions to become an entrepreneur. The theory states that behavior is a function of three factors: attitudes, subjective norms, and perceived behavioral control. This theory can adequately be used in examining entrepreneurial intentions, such as attitude towards entrepreneurship, perceived social norms towards entrepreneurship, and perceived behavior control in terms of entrepreneurship [41]. This theory was postulated by Azjen (1991) and adopted by Krueger and Carsrud (1993). In this theory, entrepreneurial behavior (EB) is a function of entrepreneurial intention (EI). In other words, Attitude equals Motivation (Behavioral control) equals Intention, and equals Behavior [15]. Based on this theory too, attitudes forming from entrepreneurship activities will ultimately relate to either being positive or negative attitudes towards behaviour [32]. Attitude towards entrepreneurship is positively related to entrepreneurial intention but there are also previous studies conducted in the United States of America stating the negative relationship between attitude and entrepreneurial intention [9][40][48].

\section{Research Methodology}

Qualitative research questions explore issues such as "Why?" and "How?" since specific human behaviours are distinctly subjective, reflecting the individual's opinions, thoughts and feelings. The qualitative method is ideally suitable for understanding the behaviors, values, and perceptions of a particular culture, or exploring unfamiliar phenomena. Qualitative studies can provide details about human behaviors, emotions, and personality characteristics that quantitative studies cannot match [20]. It can be categorized as a highly interpretive process and researchers in this method themselves play important roles in understanding the data collection method, data analysis, data interpretation, and data inference [29]. The inductive 


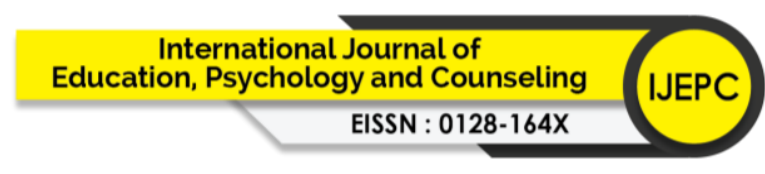

Volume 6 Issue 44 (December 2021) PP. 13-29

DOI 10.35631/IJEPC.644002

approach is concerned with generating new theories from the data that has been collected, and for this reason, is widely used for most qualitative research.

Researchers used Atlas.ti software for coding and analysing data that has been collected. Software's, such as Atlas.ti, help global researchers to validate, manage and generate relevant data for analysis and interpretations viz-z-viz on coding. Qualitative data research methodology involves six (6) main steps: 1) define objectives/problems, 2) determine research design, 3) design and prepare research instrument, 4) sampling and data collection, 5) visualize, and lastly 6) communicate end results [20]. This study employed semi-structured online interviews for data collection. Questions developed for such interviews need to meet certain research requirements to ensure reliable and accurate outcomes. In any of these methods, both parties (researchers and respondents) interact using various communication tools without face-to-face interactions. In today's global technological enhancement, this offers a significant advantage as it allows the interview protocols to be disseminated across global borders to respondents/participants without involving physical face-to-face interactions. Examples of such communication tools are WhatsApp, Skypes, or Facebook.

Instant messages can be defined as internet services that can be used in online interviews as these have features unique such as containing text messages, files (documents and pictures), and spoken language (voice messages) [39]. Among other advantages of using online instant messages is that a researcher can manage the appropriate time to conduct the interviews according to the availability and suitability of each respondent, as well as each interview can be conducted involving 2, 3, or more interview sessions. Messages transmitted can also be read and answered when the respondent is readily available.

Table 1: List Of Journals That Conducted Researches Using Online Methods

\begin{tabular}{|c|c|c|c|c|}
\hline No & Author/s & Title/Journal & Remarks & Year \\
\hline 1 & $\begin{array}{l}\text { Oseni, K.O, } \\
\text { Dingley, K \& } \\
\text { Hart, P. }\end{array}$ & $\begin{array}{l}\text { Instant Messaging and Social } \\
\text { Networks - } \\
\text { The Advantages in Online } \\
\text { Research Methodology. } \\
\text { International Journal of } \\
\text { Information and Education } \\
\text { Technology. (IJIET), (ISSN: } \\
\text { 2010-3689). }\end{array}$ & $\begin{array}{l}\text { Respondents preferred online } \\
\text { interviews (instant messages) to } \\
\text { traditional face-to-face } \\
\text { interview method since they } \\
\text { could provide feedbacks more } \\
\text { conveniently. } \\
\text { features are much faster and } \\
\text { could be answered anytime and } \\
\text { anywhere in the room. }\end{array}$ & 2018 \\
\hline 2 & $\begin{array}{l}\text { Vadi,M.G., } \\
\text { Mathew, } \\
\text { R.M., Lenart, } \\
\text { J.,Stier, G.R., } \\
\text { Gatling, J.W. } \\
\text { \& Applegate, } \\
\text { R.L. }\end{array}$ & $\begin{array}{l}\text { Comparison of web-based } \\
\text { and face-to-face interviews } \\
\text { for application to an } \\
\text { anaesthesiology training } \\
\text { program: A pilot study. } \\
\text { International Journal of } \\
\text { Medical Education. } 7: \text { Pp. } \\
\text { 102-108. }\end{array}$ & $\begin{array}{l}\text { Web-based interviews are a } \\
\text { preferred choice as compared } \\
\text { with traditional interviews due } \\
\text { to certain constraints, such as } \\
\text { travel costs, residency programs, } \\
\text { and financial limitations. }\end{array}$ & 2016 \\
\hline
\end{tabular}


Volume 6 Issue 44 (December 2021) PP. 13-29

DOI 10.35631/IJEPC.644002

\begin{tabular}{|c|l|l|l|c|}
\hline No & \multicolumn{1}{|c|}{ Author/s } & \multicolumn{1}{|c|}{ Title/Journal } & \multicolumn{1}{|c|}{ Remarks } & Year \\
\hline 3 & $\begin{array}{l}\text { Bowden, C \& } \\
\text { Galindo- } \\
\text { Gonzalez, S. }\end{array}$ & $\begin{array}{l}\text { Interviewing When You're } \\
\text { Not Face-To-Face: } \\
\text { The Use of Email Interviews } \\
\text { in a Phenomenological } \\
\text { Study. International Journal } \\
\text { of Doctoral Studies, 10, 79- } \\
92 .\end{array}$ & $\begin{array}{l}\text { The ease of technological - } \\
\text { facilitated online interviews } \\
\text { performed by using emails. This } \\
\text { is a powerful data collection } \\
\text { method and sufficient for those } \\
\text { who have good internet facilities } \\
\text { to conduct exploratory } \\
\text { researches. In addition, this } \\
\text { method is also very suitable for } \\
\text { respondents who have limited } \\
\text { time due to daily work time } \\
\text { constraints and that they are } \\
\text { more comfortable submitting } \\
\text { replies at their own convenience. }\end{array}$ & \\
\hline
\end{tabular}

In using the instant messages route, respondents can read them first, pause to think for a moment, and then be able to provide honest responses, feedbacks, or answers to the questions given or the responses may not be expected to be given instantaneously [28]. A snowball sampling method was applied. Researchers managed to obtain the name of a prospective first respondent by first initiating enquiries from researchers' own associates and friends. The minimum size (range) nature of such qualitative and interview sample size suffices between 525 participants [6]. The probability of obtaining false data is small because it can be used to obtain satisfying quality obtainable data, contact rate, response rate, and retention rate [39]. A total of 20 participants were interviewed in this research study and the snowball sampling method was adopted in this research.

\section{Results}

The data obtained were analyzed using the above-mentioned Atlas.ti software. In compiling the transcripts of the respondents, the researchers grouped the answers to form different themes using thematic analysis. It commences by creating coding, nodes, and networks that are appropriate for the study. These findings were then divided into four (4) main themes, namely (1) Demographics, (2) Factors indicating students' intentions to be involved in entrepreneurial activities, (3) Constraints, these being obstacles, and challenges to students to initiate business, and entrepreneurial activities, and (4) Products and services should be available on-site at the campus. The formation of these themes is based on theme codes for each respondent's transcript until the researchers had reached the research's saturation point. Five (5) respondents were interviewed in focus groups (using WhatsApp) whilst the remaining fifteen (15) respondents were interviewed individually (using WhatsApp). Researchers took a time frame of one (1) month, with effect from early February 2021, to collect all the data required. In order to maintain ethics for qualitative research, the researchers had provided a consent statement to each respondent before commencing each interview protocol, which acknowledged and signified each respondent's written approval and consent to be involved in this research study.

A total of 20 respondent students had participated in this research study. In terms of demographics, the majority of the 17 respondents (85\%) were Malaysians, whilst 3 respondents $(15 \%)$ were non-Malaysians, domiciled in Thailand (2 respondents) and Indonesia (1 


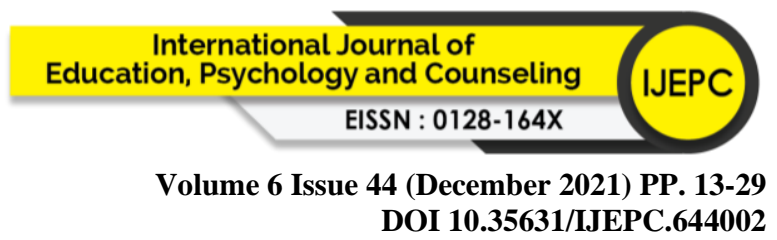

respondent). 14 respondents $(70 \%)$ were female students with the remaining 6 respondents (30\%) were males. The survey study was confined to four (4) main faculties in KUIPs, namely The Faculty of Business and Management Sciences, Faculty of Al Quran and Sunnah, Faculty of Islamic Studies, and Faculty of Muamalat and Islamic Finance, involving a total of 9, 4, 4, and 3 respondents respectively. Respondents who answered this survey included students from Semester 1 to 6 of the Bachelor's Degree and Diploma programs. Twelve (12) respondents $(60 \%)$ stated that they had family members having been involved with and having their own businesses.

Table 2: Respondent's Demographics

\begin{tabular}{|c|c|c|c|c|c|c|}
\hline No & Respondent & Nationality & Gender & Faculty & $\begin{array}{l}\text { Sem. } \\
\text { No }\end{array}$ & $\begin{array}{l}\text { Background of } \\
\text { Family Business }\end{array}$ \\
\hline 1 & Wan & Thailand & Male & Business & 5 & $\begin{array}{l}\text { Health Products \& } \\
\text { Foods. }\end{array}$ \\
\hline 2 & Zana & Malaysia & Female & Business & 5 & Selling Coconut Milk \\
\hline 3 & Aminah & Malaysia & Female & Business & 5 & $\begin{array}{l}\text { On-line } \quad \text { Health } \\
\text { Products }\end{array}$ \\
\hline 4 & Emy & Malaysia & Female & Business & 5 & $\begin{array}{l}\text { Stalls selling } \\
\text { NasiLemak and Cakes. }\end{array}$ \\
\hline 5 & Liyana & Malaysia & Female & Business & 5 & Accounting Services \\
\hline 6 & Afati & Indonesia & Female & Business & 1 & $\begin{array}{l}\text { Medical Services } \\
\text { (Azka Farma, Azka } \\
\text { Medica, Adeeba } \\
\text { Moslem Store \& } \\
\text { Cemilan Crunchy) }\end{array}$ \\
\hline 7 & Aini & Malaysia & Female & Business & 6 & $\begin{array}{l}\text { Medical Services } \\
\text { (Nurikhwah Medical } \\
\text { Services Sdn Bhd \& } \\
\text { Nisa Clinic / } \\
\text { Polyclinic) }\end{array}$ \\
\hline 8 & Nor & Malaysia & Female & Business & 5 & None \\
\hline 9 & Hakim & Thailand & Male & Business & 5 & None \\
\hline 10 & Farhan & Malaysia & Male & $\begin{array}{c}\text { Quran } \\
\& \text { Sunnah }\end{array}$ & 2 & None \\
\hline 11 & Ida & Malaysia & Female & $\begin{array}{c}\text { Quran } \\
\& \text { Sunnah }\end{array}$ & 2 & None \\
\hline 12 & Amzah & Malaysia & Male & $\begin{array}{l}\text { Quran } \\
\& \text { Sunnah }\end{array}$ & 2 & Amway \\
\hline 13 & Kifli & Malaysia & Male & $\begin{array}{c}\text { Quran } \\
\& \text { Sunnah }\end{array}$ & 2 & Florist \\
\hline
\end{tabular}


Volume 6 Issue 44 (December 2021) PP. 13-29

DOI 10.35631/IJEPC.644002

\begin{tabular}{|c|l|c|c|c|c|l|}
\hline 14 & Nana & Malaysia & Female & $\begin{array}{l}\text { Islamic } \\
\text { Studies }\end{array}$ & 2 & None \\
\hline 15 & Rahim & Malaysia & Male & $\begin{array}{l}\text { Islamic } \\
\text { Studies }\end{array}$ & 2 & $\begin{array}{l}\text { Transport } \\
\text { (iQ Aulad dan Alfateh } \\
\text { Transport) }\end{array}$ \\
\hline 16 & Siti & Malaysia & Female & $\begin{array}{l}\text { Islamic } \\
\text { Studies }\end{array}$ & 3 & None \\
\hline
\end{tabular}

\begin{tabular}{|c|l|l|l|c|c|l|}
\hline No & Respondent & Nationality & Gender & Faculty & Sem & \multicolumn{1}{|c|}{$\begin{array}{c}\text { Background of } \\
\text { Family Business }\end{array}$} \\
\hline 17 & Syaharul & Malaysia & Female & $\begin{array}{c}\text { Islamic } \\
\text { Studies }\end{array}$ & 2 & Retail Shop \\
\hline 18 & Asiah & Malaysia & Female & $\begin{array}{c}\text { Muamalat\& } \\
\text { Islamic } \\
\text { Finance }\end{array}$ & 2 & Selling Popcorn \\
\hline 19 & Omar & Malaysia & Female & $\begin{array}{c}\text { Muamalat\& } \\
\text { Islamic } \\
\text { Finance }\end{array}$ & 2 & None \\
\hline 20 & Mas & Malaysia & Female & $\begin{array}{c}\text { Muamalat\& } \\
\text { Islamic } \\
\text { Finance }\end{array}$ & 2 & None \\
\hline
\end{tabular}

Based on the coding analysis performed on the respondents' transcripts, the outcome showed that 16 out of the 20 respondents stated that they had a keen interest to start their own business and yearned to become entrepreneurs after graduation. Furthermore, 17 respondents desired to delve in business in order to meet the basic needs of users (students) in KUIPs, especially in meeting the demands for basic needs at the campus. Nevertheless, all respondents concurred that being entrepreneurs would provide them with the opportunity, as well as strong motivation, to earn extra income in order to defray part of their study as well as living expenses.

In addition, all respondents stated that the main constraint before becoming entrepreneurs in KUIPs was due to lack of capital and financial means to meet initial fixed cost necessities and payment for equipment, being pre-requisites before venturing into any business activities. The next constraint was identifying suitable business premises, followed by the need to have appropriate storage facilities (refrigerators, chillers, and freezers) for stock-keeping, especially for wet and perishable goods. Storage facilities impede thefts and pilferages. A total of 18 respondents stated that another problem for them to become entrepreneurs was their lack of entrepreneurial knowledge/skills, not being able to initiate business entrepreneurial start-ups. 


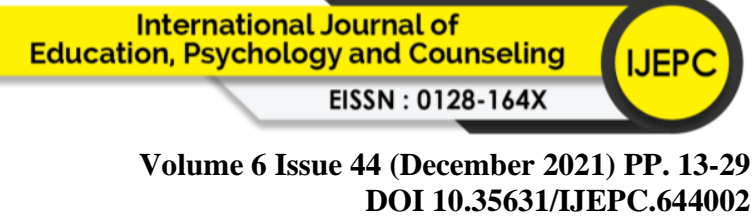

Table 3: Quotes by Respondent in forming the Study Themes

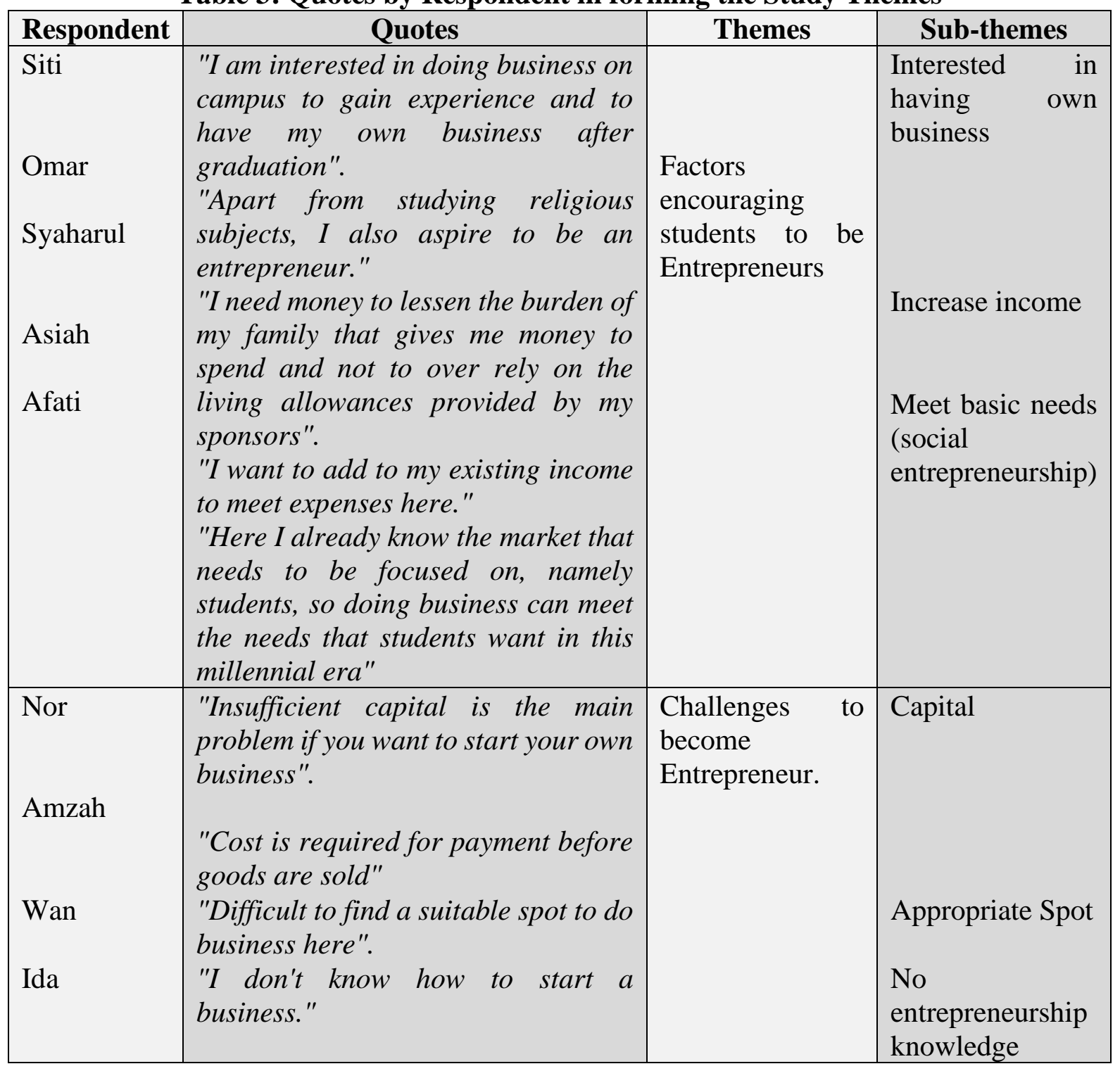




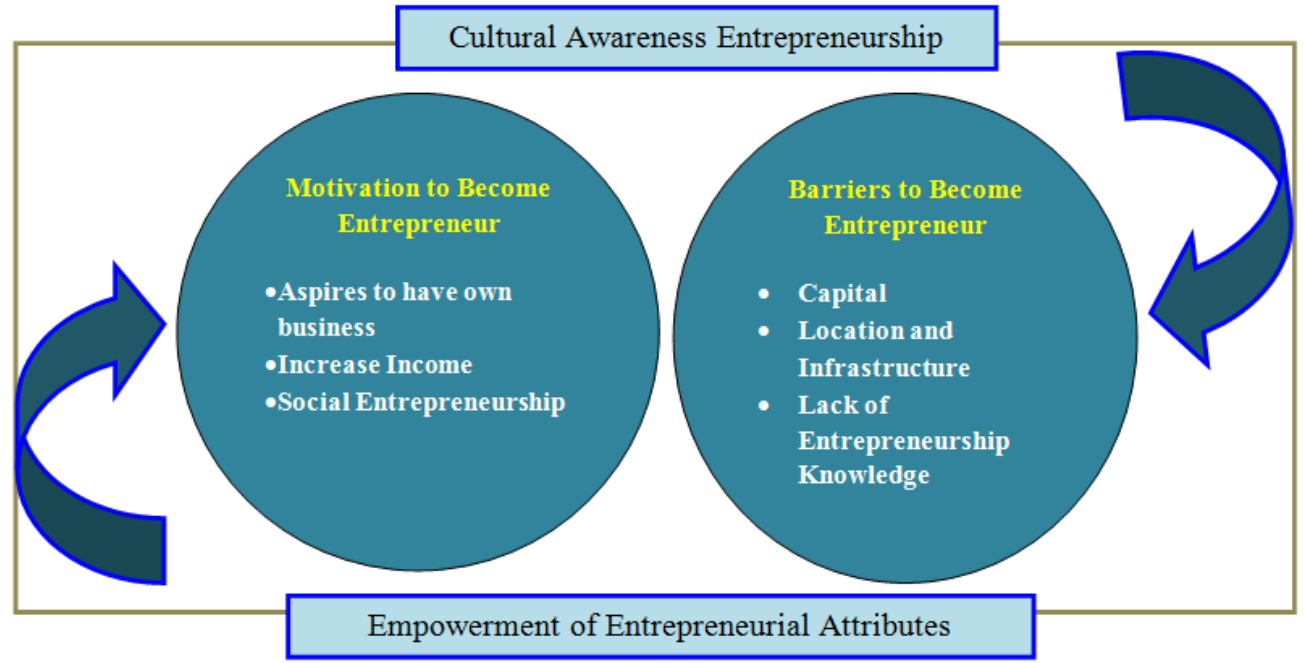

Respondents stated that since the locations of ATM (cash dispensing) machines were external and far from the college premises, which required public transport services to get to these locations, preferably the management should provide ATM machines in KUIPs for their convenience. In addition, respondents indicated their aspirations to start any form of business entrepreneurship ifthe following products and services are available on-site at the campus:

Table 4: Products \& Services of Interest to Respondents To Start Business In Campus

\begin{tabular}{|c|c|}
\hline PRODUCTS & SERVICES \\
\hline $\begin{aligned} \text { Foods } & \text { \&Beverages (Kiosks) } \\
\checkmark & \text { Drinks (other than those sold in KUIPs' } \\
& \text { cafes). } \\
\checkmark & \text { Budgeted Chicken Chops. } \\
\checkmark & \text { Spaghetti \& Pastas. } \\
\checkmark & \text { Burgers. } \\
\checkmark & \text { Snacks (pies, dessert boxes, variety of } \\
& \text { cakes). } \\
\checkmark & \text { Salads and Fruits (diet foods). } \\
\checkmark & \text { Boba drinks. } \\
\checkmark & \text { Fast Foods \& Popcorns. } \\
\checkmark & \text { Roti Canai. } \\
\checkmark & \text { Nuts. } \\
\checkmark & \text { Fruits and Mixed Fruits. } \\
\checkmark & \end{aligned}$ & $\begin{array}{l}\text { Transports (Grabs) for Students } \\
\checkmark \text { Limited public transport available. } \\
\checkmark \text { Locality - purchasing essential } \\
\text { items are very far from hostels. }\end{array}$ \\
\hline $\begin{array}{l}\text { Cooperatives/ Mini Marts } \\
\checkmark \text { Essential items (soap, shampoo, } \\
\text { toothpaste, toothbrush, sanitary } \\
\text { napkins, hand \& leg stockings) } \\
\checkmark \text { Bread \& Snacks. } \\
\checkmark \\
\text { Sardines, Tuna, Peanut Butter \&Fruit } \\
\text { Jams. }\end{array}$ & 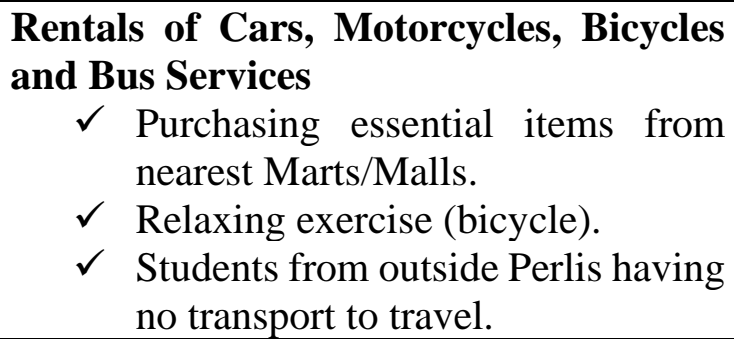 \\
\hline
\end{tabular}


Volume 6 Issue 44 (December 2021) PP. 13-29

DOI 10.35631/IJEPC.644002

\begin{tabular}{|c|c|}
\hline$\checkmark \quad$ Biscuits, Canned \& Bottled Drinks. & $\begin{array}{l}\checkmark \text { Transportation to mosque for } \\
\text { Friday prayers. }\end{array}$ \\
\hline $\begin{array}{ll}\text { Food Trucks } \\
\checkmark & \text { Variety Dishes (Lunch). } \\
\checkmark & \text { Foods \& Beverages. } \\
\checkmark & \text { Iced blended drinks. } \\
\end{array}$ & $\begin{array}{l}\text { Entrepreneurship Training } \\
\checkmark \checkmark \text { Entrepreneurship Skills before } \\
\text { starting a Business. }\end{array}$ \\
\hline $\begin{array}{ll}\text { Stationeries } \\
\checkmark & \text { Pens, Papers, Books. } \\
\checkmark & \text { Sticky papers. } \\
\checkmark & \text { Highlighters. } \\
\end{array}$ & $\begin{aligned} \text { Prints \& Copiers } \\
\checkmark \quad \text { Printing and Copying of notes and } \\
\text { assignment given by Lecturers. } \\
\checkmark \quad \text { Sale of Arabic Books } \\
\end{aligned}$ \\
\hline $\begin{array}{l}\text { Coffee Shops and Bakeries } \\
\checkmark \quad \text { Student's Own Products (Bread } \\
\quad \text { \&Donuts) } \\
\checkmark \text { Sourced from Suppliers }\end{array}$ & $\begin{array}{l}\text { Internet / Data Plans } \\
\quad \checkmark \text { Data Top Ups \& Internet Packages. } \\
\checkmark \checkmark \text { Wi-Fi }\end{array}$ \\
\hline \begin{aligned} & \multicolumn{3}{l}{ Vendor Kiosks } \\
&$\checkmark$ Scarves \& T-Shirts. \\
&$\checkmark$ Light Snacks \& Chips. \\
&$\checkmark$ Cakes \& Delicacies. \\
&$\checkmark$ Biscuits \& Pastries. \end{aligned} & $\begin{array}{l}\text { Gymnasium } \\
\quad \checkmark \quad \text { For health \& recreation. }\end{array}$ \\
\hline $\begin{array}{l}\text { Accessories } \\
\quad \checkmark \quad \begin{array}{l}\text { Shirts / T- Shirts (printed with KUIPs' } \\
\text { name). }\end{array}\end{array}$ & $\begin{array}{l}\text { Barber Shop } \\
\quad \checkmark \text { Hair Salons. }\end{array}$ \\
\hline
\end{tabular}

Therefore, there is an immediate need to design and develop an appropriate module(s) for entrepreneurship cultural awareness and empowerment of entrepreneurial attributes among students so that entrepreneurial ecosystem activities can be realised at KUIPs.

\section{Conclusion And Recommendation}

Overall, the study results obtained from this case study are concurrent with previous studies conducted by past researchers on the factors and challenges facing them to become entrepreneurs. This study has successfully achieved the objectives set earlier for research in the field of entrepreneurship. The main factor of students aspiring to be entrepreneurs, to supplement income and have their own business, is significant with previous studies [38][42][10]. In addition, the desire of students who aspire to do business to meet the needs of users (other students) is also affected by the concept of social entrepreneurship, which is growing in Malaysia [35]. Capital and availability of infrastructure facilities for students to start a business need to be emphasized by the university's management if they want students to be actively involved in these activities [10][3]. Challenges to start an entrepreneurship career are also related to students 'exposure to the knowledge and culture of entrepreneurship itself, including training programs in entrepreneurship, undergraduate and postgraduate level entrepreneurship study programs [22][14]. Therefore, KUIPs need to develop entrepreneurship programs in terms of facilitating students to carry out entrepreneurial activities among these students based on the results of the study discussed above. Short courses on entrepreneurship, appropriate infrastructures, and availability of capital or financial assistance for students to run a business are important in entrepreneurship cultural awareness and empowerment of entrepreneurial attributes among them. Entrepreneurship advisories from lecturers and external 


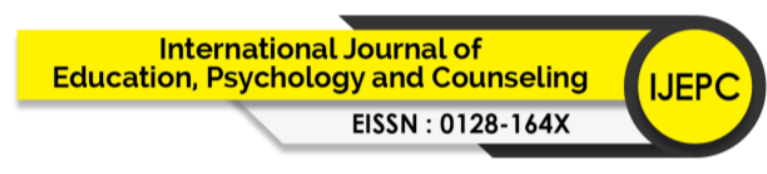

Volume 6 Issue 44 (December 2021) PP. 13-29

DOI 10.35631/IJEPC.644002

parties can be created to provide specific guidance to students to run their businesses successfully.

\section{Limitations of Study}

This study examines specific issues on entrepreneurship cultural awareness and entrepreneurship attributes among students in a single HEI in Perlis. The outcomes of the findings show the presence of social entrepreneurship awareness attribute among students in having the intentions to meet the needs and demands of other co-students. Social entrepreneurship awareness has not only become a common attribute and trend in Malaysia's HEIs but also worldwide. This attribute enables aspiring entrepreneurs (university students) to come out with a proper business plan to search for available capital to fulfill their social mission in pursuit of the entrepreneurship journey. Secondly, this social entrepreneurship awareness attribute can increase students' responsibility towards society. As this study only involves a small sample size of 20 student respondents in a single private HEI in Perlis, the results of the study can only be used as preliminary data for these specific fields. The study scopes and parameters should be expanded beyond KUIPs to include other HEIs in Perlis and as well as from other states in Malaysia so as improve the generalisation results as a whole.

\section{References}

Abualbasal, A.M and Badran, R.E. (2019). Students' Attitude Towards Entrepreneurship At Princess Sumaya University For Technology. Journal of Entrepreneurship Education.22(1) 2019. Pp. 1 - 19.

Ajzen, I. (1991). The Theory of Planned Behaviour. Organizational Behaviour and Human Decision Processes. Vol. 50, pp. 179-211.

Bakheet, A.H. (2018). Student Perceptions On Business Opportunities And Barriers For Business Start-Up In Oman. International Journal of Entrepreneurship. 22(1) 2018.Pp. 1- 8.

Bowden, C \& Galindo-Gonzalez, S. (2015). Interviewing When You're Not Face-To-Face: The Use of Email Interviews in a Phenomenological Study. International Journal of Doctoral Studies, 10, 79-92.

Kvale, S. and Brinkmann, S. (2009) Interviews learning the craft of qualitative research interviewing. Sage Publications, Los Angeles. Retrieved from: https://www.scirp.org/reference/ReferencesPapers.aspx?ReferenceID=478372.

Creswell, J. W. (1998). Qualitative inquiry and research design: Choosing among five traditions. Thousand Oaks, CA, US: Sage Publications, Inc.

Eze, T. I., Ezenwafor, J. I., Igberaharha, C. O. (2016). Assessment Of Entrepreneurial Skills Needed For Self-Employment By Business Education Graduates In Delta State, Nigeria. European Journal of Management and Marketing Studies. 1(1). Pp. 1 - 14.

Fasla, N.P. (2017). A Study on Entrepreneurship Attitude Among University College. International Journal of Research Science and Management. ISSN 2349 - 5197. Pp. $53-59$.

Jianfeng Yang. (2013). The theory of planned behavior and prediction of entrepreneurial intention among Chinese undergraduates. Social Behavior and Personality. 41(3), 367 376.

Katrodia, A. and Siband, R. (2018).Challenges Experienced By Young Entrepreneurs Entering The Small And Medium Enterprise Sector (Sme) In Rajkot Region, Gujarat-India. Academy of Entrepreneurship Journal. 24(4), 2018. Pp. 1 - 14. 


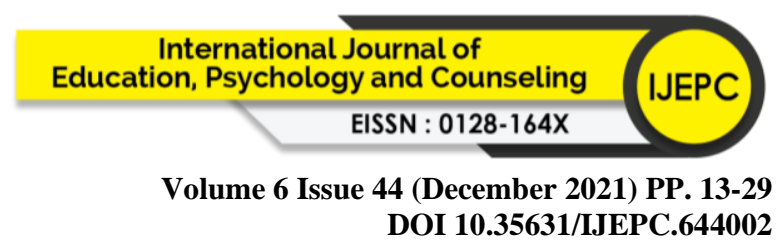

Kefale, D. and Hussain, F. (2020). Challenges of Entrepreneurs Live with Disabilities to Establish and Expand Their Own Business in Case of Guraghe Zone, Ethiopia. p-ISSN: 2162-9374, e-ISSN: 2162-8416 2020; 10(2): 55-69 doi:10.5923/j.mm.20201002.03.

Kementerian PelajaranTinggi Malaysia.(2021). 20 Universiti Awam Malaysia 2021. Retrieved on May, 26, 2021 from: http://dev.mohe.gov.my/institusi/universiti-awam.

Kementerian Pelajaran Tinggi Malaysia. (2021). Universiti Swasta Malaysia 2019. Retrieved on May, 26, 2021 from: https://www.upuonline.com/ipts.jsp.

Khuong, M.N. and An, N.H. (2016). The Factors Affecting Entrepreneurial Intention of the Students of Vietnam National University- A Mediation Analysis of Perception toward Entrepreneurship. Journal of Economics, Business and Management. 4(2). Pp. 104 111.

Krueger, N. and Carsrud, A. L. (1993). Entrepreneurial Intentions: Applying the theory of 65) Planned Behaiour. Entrepreneurship and Regional Development .5, pp. 315-330.

Kurniawan, M.E.H., Yudoko, G., Basri, M.H., danUmbara, A.N (2019). Do Entrepreneurship Students Have An Intention To Become An Entrepreneur? Journal of Entrepreneurship Education. 22(2), 2019. Pp. 1 - 14.

Jayalakshmi, P. and Saranya, A.S. (2015).Entrepreneurial Intention Among Students Of Arts And Science Colleges In Chennai - An Empirical Study. International Journal on Information Sciences and Computing. 9(1) January 2015. Pp. $1-12$.

Legas, H. (2015). European Journal of Business and Management. Challenges to Entrepreneurial Success in Sub-Saharan Africa: A Comparative Perspective. 7(11), 23 35.

Love, C.N. (2008). Entrepreneurship: A conceptual approach :Lagos:m Pumark.

Madrigal., D \& McClain., B. (2012). Strengths and weaknesses of quantitative and qualitative research. Retrieved from: http://www.uxmatters.com/mt/archives/2012/09/strengthsand-weaknesses-of-quantitative-and-qualitative-research.php

Mahdin, N. (2018). Challenges of Young Entrepreneur.Research Hub.4(11). ISSN: 2180-0065. Pp. $14-18$.

Mai N.Q. and Anh P. T. (2013). Factors affecting small enterprises in Vietnam. International Journal of Business and Social Science. 5(1), pp. 53-62.

Malhotra, N.K. and Birks, D.F. (2003). Marketing Research: An Applied Approach, UK: Pearson Education.

Massad, V.J. \& Tucker, J.M. (2009). Using Students Managed Businesses to integrate the business curriculum. Journal of Instructional Pedagogies. 1, Pp. 17 - 29.

Maziriri, E.T., \&Madinga, N.W. (2016). A Qualitative Study on the Challenges Faced by Entrepreneurs Living with Physical Disabilities within the Sebokeng Township of South Africa. International Journal of Research in Business Studies and Management. 3(5), May 2016, 1-13.

Mohd.Wahid, S. D., Hussain, W. M. H. W., \&Ayob, A. H. (2018).The Growing Trend of Social Entrepreneurship among Malaysian Undergraduate Students. International Journal of Academic Research in Business and Social Sciences. 8(9), 1034-1046.

Mukherjee, K. (2016). The Psychology of the Successful Entrepreneur. International Journal of Advanced Engineering and Management. 1(1), PP. 25-32, 2016.

Mynett, E., Voida, A., Erickson, T. \& Kellogg, W. (2004). Interviewing Over Instant Messaging. ACM Press: New York.

Nakash, O., Nagar, M., Shoshani, A., \& Lurie, I. (2015).The association between acculturation patterns and mental health symptoms among Eritrean and Sudanese asylum seekers in Israel. Cultural Diversity and Ethnic Minority Psychology, 21(3), 468-476. 


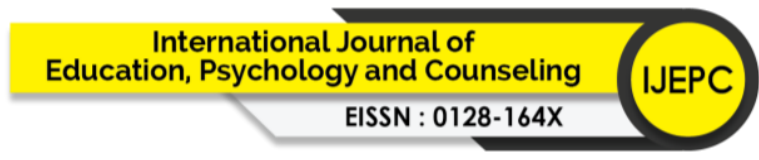

Volume 6 Issue 44 (December 2021) PP. 13-29

DOI 10.35631/IJEPC.644002

Ogbaekirigwe, C.O., Ituma, A. and Igwe, P.A. (2020). Introduction to Entrepreneurship/Intrapreneurship. Retrieved on May 27, 2021 from: https://www.researchgate.net/publication/342439196.

Oseni, K.O, Dingley, K \& Hart, P. (2016). Instant Messaging and Social Networks - The Advantages in Online Research Methodology. International Journal of Information and Education Technology. (IJIET), (ISSN: 2010-3689).

Radzi, N.F. (2019). Factors Influencing Entrepreneurship Intention Among Students. 2019 Jurnal Kejuruteraan, Teknologi dan Sains Sosial.1 (1) (Special Issue - NaCoSC'19).

Rahim, H.L., Abdul Kadir, M.A.B., Zainal Abidin, A., Junid, J., Kamarudin, L. Mohd Lajin, N.F, Buyong, S.Z and Ahmad Bakri, A. (2015). Entrepreneurship Education In Malaysia: A Critical Review. Journal of Technology Management and Business. (ISSN: 2289-7224) 2(2), 2015. Pp. 1 - 11.

Rao, R.K., Arora, S. and Marwah, P. (2018). Social Entrepreneurship: A Few Case Study. International Research Journal of Commerce Arts and Science. 9(1), Pp. 55 - 60.

Rashid, N. S., Sarkam, S. F., Yaacob, N. J. A., Mustapha, M., Jusoh@Hussain, N., \& Azis, R. A. (2018).Factors Influencing Student's Social Entrepreneurship Intention: A Case of Duta Jauhar Program. International Journal of Academic Research in Business and Social Sciences. 8(4), 1285-1299.

Shanmugan (2017). Unemployment among graduates needs to be sorted out fast. The Star Online. Retrieved on May 20, 2021 from: https://www.thestar.com.my/business/businessnews/2017/03/25/unemploymentamong -graduates-needs-to-sorted-out-fast/.

Shambare, R. (2013). Barriers to Student Entrepreneurship in South Africa. Journal of Economics and Behavioral Studies.5(7). Pp. 449 - 459. ISSN: 2220 - 6140.

Shiri, M, Mohammadi, D and Hosseini, S. M. (2012). Entrepreneurial Intention of Agricultural Students: Effects of Role Model, Social Support, Social Norms and Perceived Desirability [Online]. Archives of Applied Science Research, 4 (2):892-897 Available from: http://scholarsresearchlibrary.com/aasr-vol4-iss2/AASR-2012-4-2-892-897.pdf. [Retrieved on 01 May 2021].

Stiegger, S. \& Goritz A.S. (2006). Using Instant Messaging for Internet-Based Interviews. Cyberpsychology \& Behavior Journal. 9(5), 2006, pp 552 - 559.

Tegtmeier, S. (2012). Empirical implications for promoting students's entrepreneurial intentions. Journal of Enterprising Culture, 20 (No. 2), 151-169.

Tahir, M. (2018). Application Of Theory Of Planned Behavior For Understanding Entrepreneurship Intention Among Female University Students In Pakistan. Journal Of Research And Reviews In Social Sciences Pakistan. 1 (1), 2018 Pp 1-6.

Tamahane, T.C., Chetty, N. and Karodia, A.M. (2017). Factors That Influence Entrepreneurship In University Students: A Case Study Of Two Departments At The University Of The Western Cape (Republic Of South Africa). Kuwait Chapter of Arabian Journal of Business and Management Review. 6(6). February 2017. Pp. 1 - 30.

Tanveer, M.S., Zfar, S., Shafique, S., Jhangir, M. and Rizvi, S. (2013). Motivational factors and students' entrepreneurial intentions in Pakistan. Journal Basic Applied Scientific Research. 3(4) 263 -269.

Uddin, M. M., Chowdhury, M. M., \& Ullah, M. M. (2015). Global Journal of Management and Business Research: Administration and Management. Barriers and Incentives for Youth Entrepreneurship Start-Ups: Evidence from Bangladesh, 15(4), 1-12. 


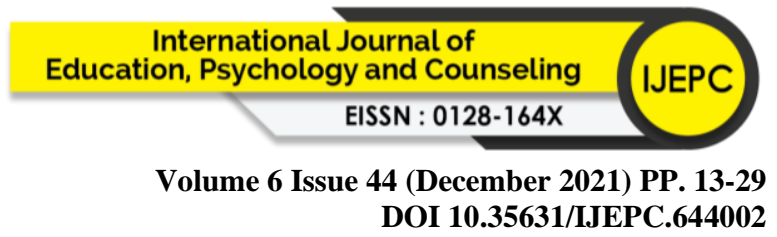

Upadhaya, G. and Chadha, P. (2019). Key Determinants of Entrepreneurial Intention Among Students: A Literature Review. Administrative Development: A Journal of HIPA, Shimla. VI(2), 2019. Pp. 1 - 14.

Usen, S.M, Jimmy, Edet, J., Udokang, M. (2018). Marketing Skills Needed for Self-Reliance among Business Education Students in the University of Uyo. International Journal Of Educational Benchmark (IJEB). eISSN: 2489-0170pISSN:2489-4162. Pp. 88 - 96.

Zainal Adnan, A. Z., Rosdi, S. A. M., Hudin, N. S., \& Razak, A. Z. A. A. (2019). Integrating Religious Values in Entrepreneurship Activities among Malaysian Undergraduates Students. International Journal of Academic Research in Business and Social Sciences.9(8), 14-21.

Zhang, P., Wang, D. D., \& Owen, C. L. (2015). A Study of Entrepreneurial Intention of University Students. Entrepreneurship Research Journal. 5(1), 61-82. 